Website: http://jsci.utq.edu.iq

Email: utjsci@utq.edu.iq

\title{
Assessment of electrolytes and HbA1c in type 2 diabetic patients using metformin and evaluation of guidelines obedience regarding renal impairment
}

\author{
Rua Abbas Naser Al-Hamdy \\ Department of Clinical and Basic Sciences-College of Pharmacy-Thi-Qar University \\ Phone no.07807173271, Email: pharmacol_2014@yahoo.com
}

\section{Abstract:}

Metformin is indicated as the first line treatment in type 2 diabetes mellitus (T2DM). The objectives of this study were to assess electrolytes and glycosylated haemoglobin (Hb1 Ac) in patients with T2DM using metformin for long term therapy and also to demonstrate compliance with the guidelines regarding renal impairment. This study has been conducted in Al-Nassiriya Province. It was carried out on sixty patients (with T2DM for 5 years, age: 50-60 years).

We found that $43 \%$ of physicians use creatinine levels as a test for follow up while the others use urea and/ or glomerular filtration rate (GFR). Only $57.2 \%$ of physicians follow the guidelines by doing the test every three months.

The results showed high potassium and low sodium levels in patients treated with metformin only compared with other oral hypoglycaemic agents (OHAs). However, both were still within the normal level and statistically insignificant (P > 0.005). Calcium readings were high in patients treated with metformin compared with other OHAs and were statistically significant $(\mathrm{P}<0.005)$, but still within the upper normal level. HbA1c was low $(7.33 \%)$ in patients treated with metformin combined with other OHAs compared with HbA1c in patients treated with metformin only which was $9.48 \%$ and was statistically significant $(\mathrm{P}<0.005)$. We need more clinical studies about electrolytes association with metformin. HbA1c should be taken in consideration when treating type 2 diabetes with metformin as initial therapy alone or in combination with other OHAs and /or withdrawn from metformin.

Keywords: type 2 diabetes mellitus, metformin, oral hypoglycemic agents, renal impairment, HbA1c, electrolytes.

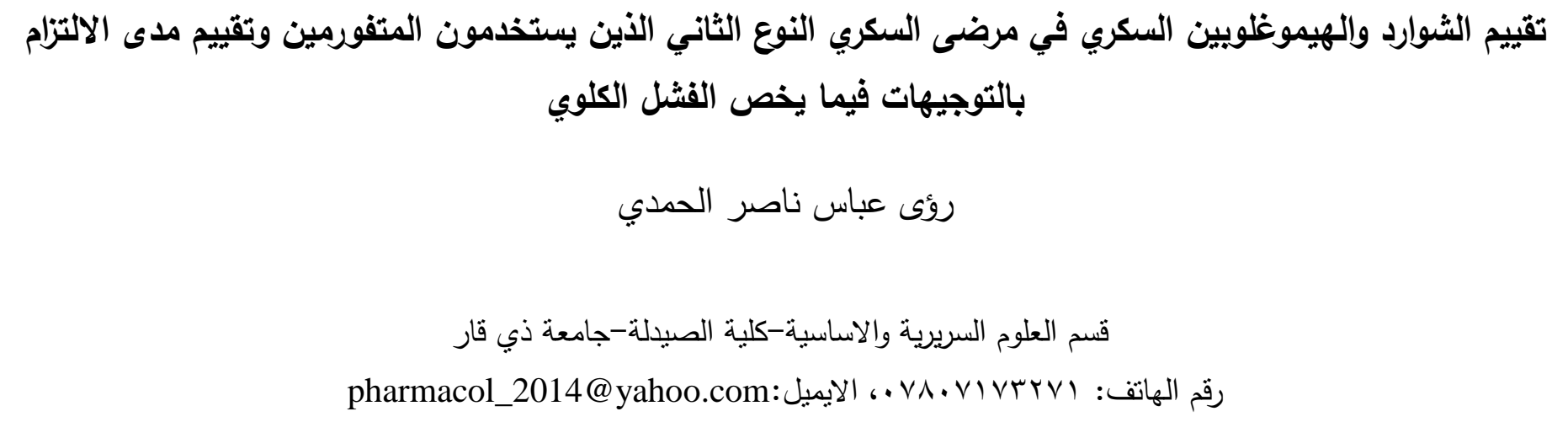

الخلاصة:

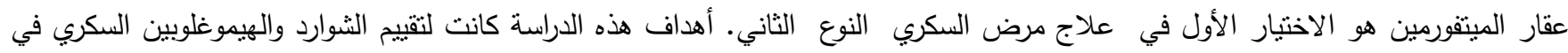

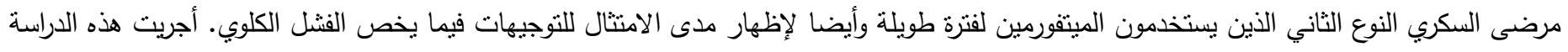

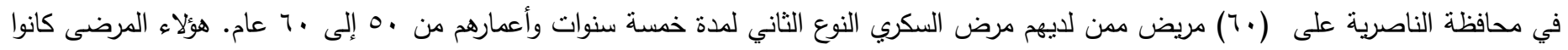

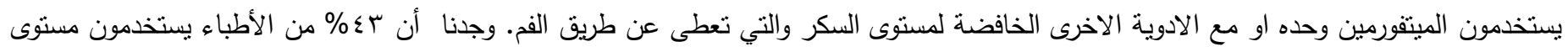


الكرياتتين كأختبار للمتابعة ، بينما يستخدم الآخرون اليوريا و/أو سرعة الترشيح الكبيبي. \%ov من الاطباء يتبعون التوجيهات و يقومون بالاختبار كل r شهور • اظهرت النتائج أن مستوى البوتاسيوم كان عاليا والصوديوم منخفضا لدى المرضى اللذين يستخدمون الميتفورمين وحده مقارنة مع الادوية الاخرى الخافضة لمستوى السكر والتي تعطى عن طريق الفم. ومع ذللك، كانت مستويات الصوديوم والبوتاسيوم ضمن المستوى الطبيعي ولا أهمية لها إحصائيا

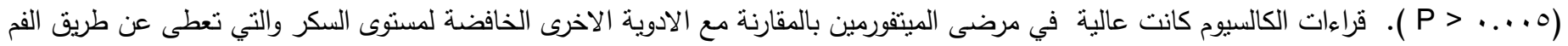
وكانت مهمه احصائيا (0 . . • > P) ولكنها ضمن الحد الاعلى للمستوى الطبيعي. الهيموغلوبين السكري كان منخفضا (rس.V \%) في المرضى الذين بستخدمون الميتفورين مع الادوية الاخرى الخافضة لمستوى السكر والتي تعطى عن طريق الفم مقارنة مع الهيموغلوبين السكري للمرضى الذين بستخدمون

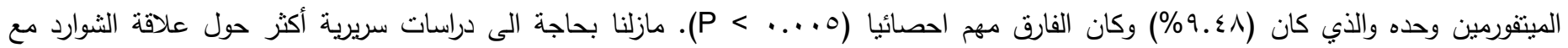
الميتفورمين. الهيموغلوبين السكري ينبغي أن يؤخذ بنظر الاعتبار عند معالجة مرضى السكري النوع الثاني مع الميتفورمين كعلاج اولي وحده او مع الادوية الاخرى الخافضة لمستوى السكر والتي تعطى عن طريق الفم او عندما يتم تغبير العلاج من الميتقورمين بسبب عدم تحقيق المسنوى المستهدف للهيموغلوبين السكري.

الكلمات المفتاحية: مرض السكري النوع الثاني، الميتفورين،الادوية الخافضة لمستوى السكر والتي تعطى عن طريق الفم، الفشل الكلوي، الهيموغلوبين السكري، الشوارد.

\section{Introduction:}

Diabetes is defined as a metabolic disorder characterised by increase of the blood glucose due to defects in insulin secretion, insulin action, or both. Type 2 diabetes is a combination of insulin resistance in the liver and muscle in addition to the impaired insulin secretion form the B-cell of the pancreas. It contributes to 90 to $95 \%$ of all diabetes. Type 2 diabetes is highly prevalent globally with wide range of variation $0-5,300$ per 100,000 population (Fazeli Farsani et al., 2013). There is no absolute deficiency of insulin and other autoimmune diseases do not coexist. Genetic factors are the major etiological factor in type 2, polymorphic genes are to be blamed which contribute to $20 \%$ of diabetes type 2 and found in the subunit of B-cell. Other environmental factors also increase susceptibility of this form like obesity, lack of exercises and with age.(Kahn et al., 2014) (American Diabetes, 2011). Metformin is the commonest agent used and the firstline drug treatment for type 2 diabetes. The mechanism of action is by enhancing insulin sensitivity and increasing glucose uptake, decreases glucose absorption from the gut, and increases fatty acid oxidation (Rena et al., 2013). Glycated haemoglobin (GHB), reported as haemoglobin A1c (HbA1c), is gold standard test to monitor long-term glycemic control and assess the risk of developing complications (Group, 1993, Group, 1998b). Although the target level of HbA1c is different between countries but WHO has determined the cut point at $6.5 \%$ for DM type 2, and for those at risk of hypoglycaemic risk is to be $7.5 \%$ (Walker et al., 2014).
Although metformin is the first line of treatment when the HbA1c is above 7\% (Group, 1998a), recent studies showed that combination of two oral hypoglycemic agents significantly decrease HbA1c compared to monotherapy of metformin (Reasner et al., 2011). However, adding metformin to insulin was significantly more effective of $\mathrm{HbA} 1 \mathrm{c}$ reduction than insulin alone (Hemmingsen et al., 2012). The main guidelines for metformin use are based with respect to the renal function although it might be different in terms of which marker taken in consideration. For instance, US Food and Drug Administration (FDA) recommend that metformin should be contraindicated if the serum creatinine is $\geq 1.5 \mathrm{mg} / \mathrm{dl}$ for male and $\geq 1.4 \mathrm{mg} / \mathrm{dl}$ for women. Additionally, metformin should not be started for patient $\geq 80$ years unless renal function is shown to be unreduced. (Administration, 2014). Nevertheless, the estimated glomeruler filtration rate (eGFR) is widely used as a cut point. For example, in the UK the national institute for health and clinical excellence they use eGFR below $30 \mathrm{ml} / \mathrm{min}$ per $1.73 \mathrm{~m} 2$ (Clinical and Excellence, 2015, KDOQI, 2015). Metformin is excreted unchanged by kidneys and might accumulate in patient with renal failure (Sambol et al., 1995). However, metformin serum level is generally maintained within the normal therapeutic range even for those patients with renal dysfunction(Frid et al., 2010). Therefore, drug level measurement has neither therapeutic nor diagnostic significance (Inzucchi et al., 2014). A few studies had been conducted on electrolyte changes of patients taking metformin. Treatments of diabetic patients with metformin shows elevated serum 
$\mathrm{Ca}+2$ level and insignificant elevation of potassium and reduction of sodium values (Javaid et al., 2007).

\section{Materials and methods:}

\section{Patients:}

Sixty patients (50 to 60 years old, having T2DM for 5 years) were examined and investigated in Dr.Thaer Jabbar's clinic and Dr. Riyadh Khayon's clinic in AlNassiriya city. Selection criterion was metformin or other OHA ( Glibenclamide, Glimepiride, Repaglinid ) and metformin as combined or monotherapy. Blood samples were taken and processed for $\mathrm{K}+, \mathrm{Na}+\mathrm{Ca}+2$ and $\mathrm{Hb} 1 \mathrm{Ac}$.

\section{Biochemical essay:}

ARCHITECT -AEROSET Abbot c4000 was used for Biochemical essay. Essay included creatinine estimation through Alkaline Picrate methodology (Bowers and Wong, 1980). Calcium essay was performed via Arsenazo III methodology (Janssen and Helbing, 1991). Both potassium and sodium were assessed by The ICT technology (Integrated Chip Technology) via application of ion selective electrodes of diluted (indirect) (Tietz NW, 1994). Urea was measured by unease which was originally enzymatic essay described by Talke and Schubert (Talke and Schubert, 1965).The samples were collected via traditional venipuncture (apart from tourniquet exclusion to avoid artefact with calcium reading), with using of heparin as an anticoagulant. (McMullan et al., 1990). Blood sample were dealt with automated dilution protocol with normal saline via Abbott system.

For HbAlc evaluation, cation exchange high performance liquid chromatography (CE-HPLC) (Sofronescu, 2013) was used.

\section{Survey:}

A questionnaire was asked to 20 physicians about the obedience with guidelines of metformin, whether they considered it as first line, or they preferred combination, what was their markers for follow up and how often they do this test.

\section{Statistics:}

The statistics was done using both Microsoft office Excel and SPSS version 17.11 to calculate the results.(mean, standard deviation, standard error). Independent T-Test was used to compare metformin patients' results with other hypoglycaemic agent and $\mathrm{P}$ value was calculated ( $\mathrm{P}$ value less than 0.005 was considered significant).

\section{Results:}

The survey for all metformin therapy showed that $54.29 \%$ of patients were on metformin only while $45.71 \%$ were on metformin combined with other OHAs ( Figure 1). However, most of the patients had metformin started since the diagnosis, where they counted for $84.29 \%$ while the other $15.71 \%$ were switched from other OHAs (Figure 2).

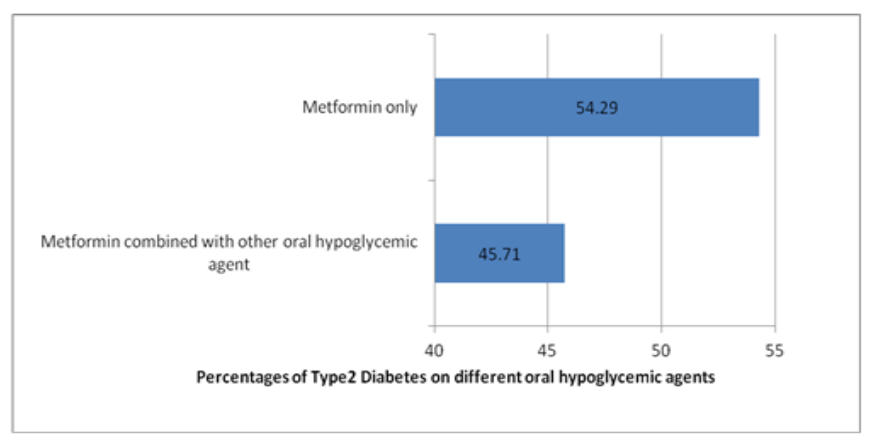

Figure 1. Type 2 diabetic pateints using metformin versus patients using metformin combined with other oral hypoglycemic agent.

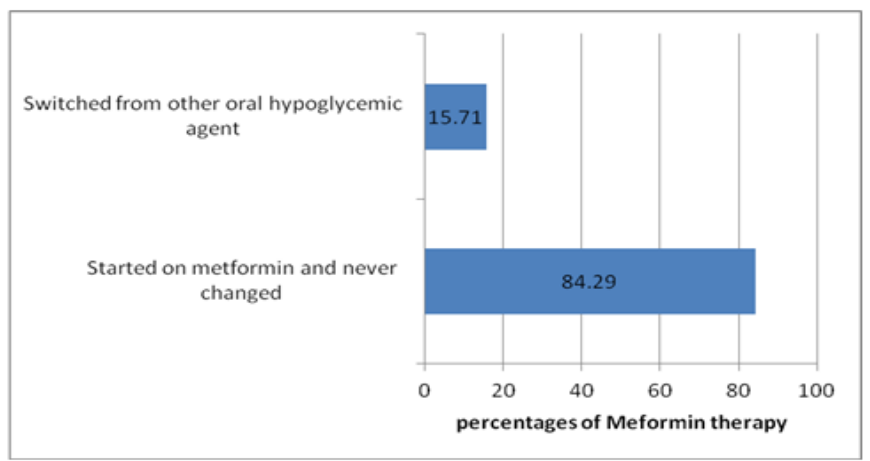

Figure 2 . Comparison between initial metformin therapy and switching from other oral hypoglycaemic agent.

In terms of the clinical investigations used as a reliable marker for follow up of renal function, about $43 \%$ of physicians use creatinine level as sole marker, $42.9 \%$ use both creatinine and urea as reliable markers, and $14.1 \%$ use both urea and GFR as markers (Figure 3) 


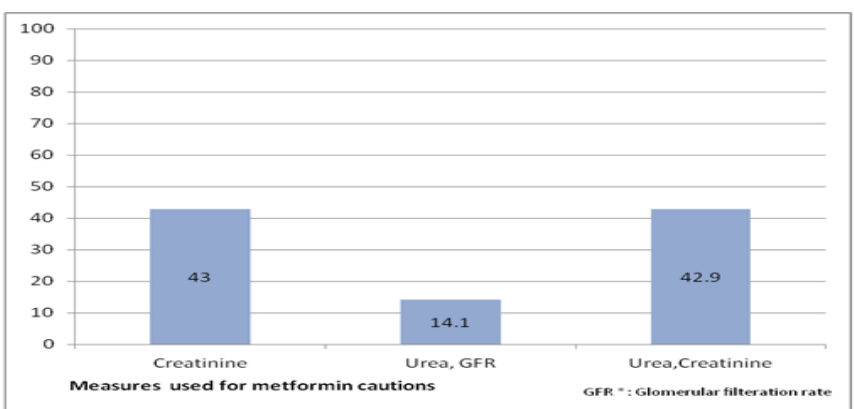

Figure 3. Percentages of physicians using certain clinical investigations as a reliable marker for renal function while patient is on metformin.

Regarding time scale frequency for follow up of renal function while patient is on metformin, only $57.2 \%$ of physcians follow the guidelines by doing the test every three months, while $28.5 \%$ of physcians do the test every two months and $14.3 \%$ of physcians do the test every one year (Figure 4).

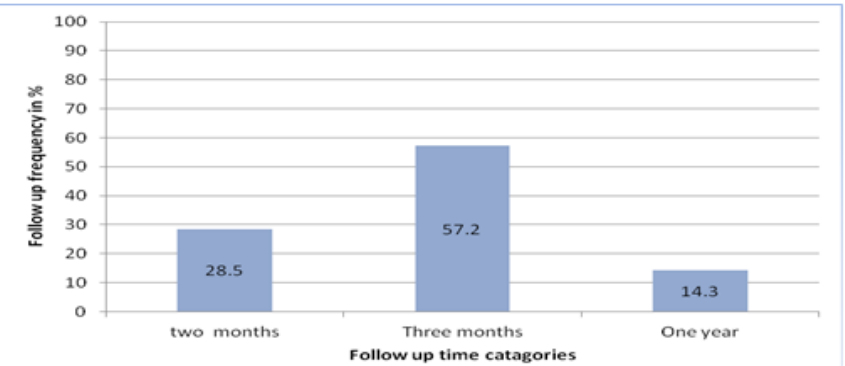

Figure 4. Percentages of physicians using different time categories for follow up of renal function while patient is on metformin.

The lab results showed that the mean value of potassium level was $4.4 \mathrm{mEq} / \mathrm{l}$ for those who were on metformin compared with $4.3 \mathrm{mEq} / \mathrm{l}$ who were on other OHAs. However, the difference was statistically insignificant ( $\mathrm{P}$ value is 0.659) (Standard error= 0.006028 and 0.001048 respectively) (Figure 5).

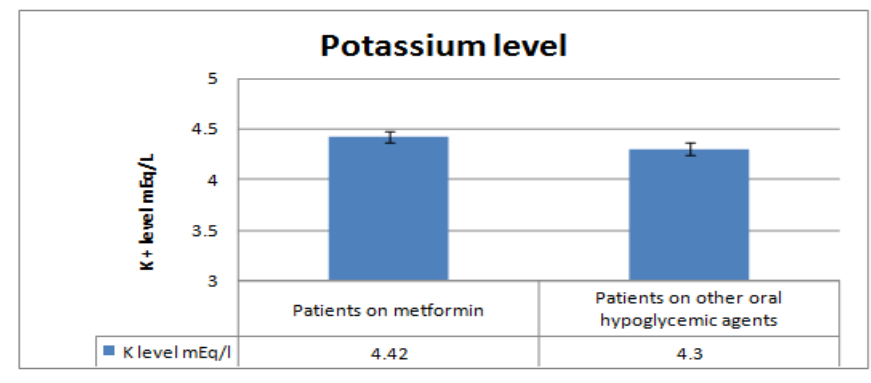

Figure 5. Potassium level in patients on metformin versus patients on other oral hypoglycemic agents.
Patient on metformin only had lower sodium level with mean average of $136 \mathrm{mmol} / \mathrm{L}$ compared with 140 $\mathrm{mmol} / \mathrm{L}$ for those on other OHAs. The mean different was statistically insignificant $(\mathrm{P}$ value $=0.451)$ (independent T-test was used) yet it is within the normal upper value(standard error $=0.106299$ and 0.17766 respectively) . (Figure 6)

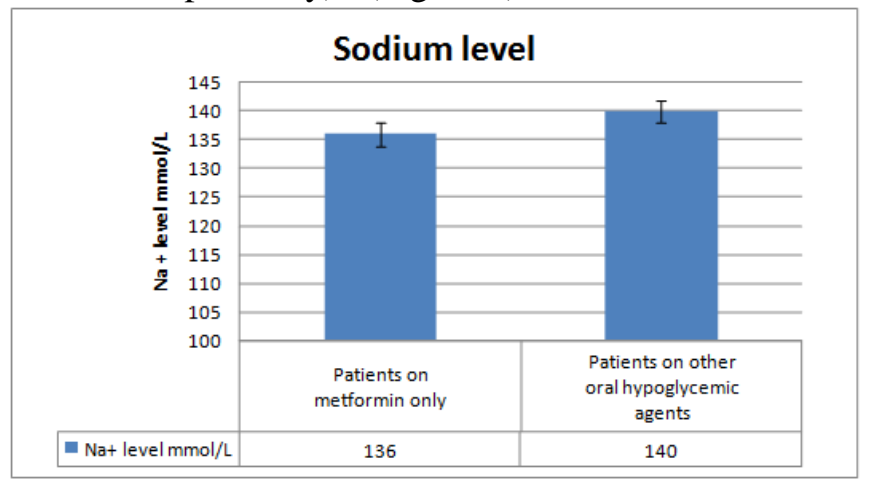

Figure 6. Sodium level in patients on metformin versus patients on other oral hypoglycemic agents.

There was a significant increase $(\mathrm{P}$ value $<0.05)$ of calcium level (mean average is $10 \mathrm{mg} / \mathrm{dL}$ ) in patients using metformin alone compared to other patients using other OHAs (mean was $8.8 \mathrm{mg} / \mathrm{dL}$ ). However, both readings were within normal limits of calcium level (standard error $=0.100844$ and 0.016468 respectively) (Figure 7).

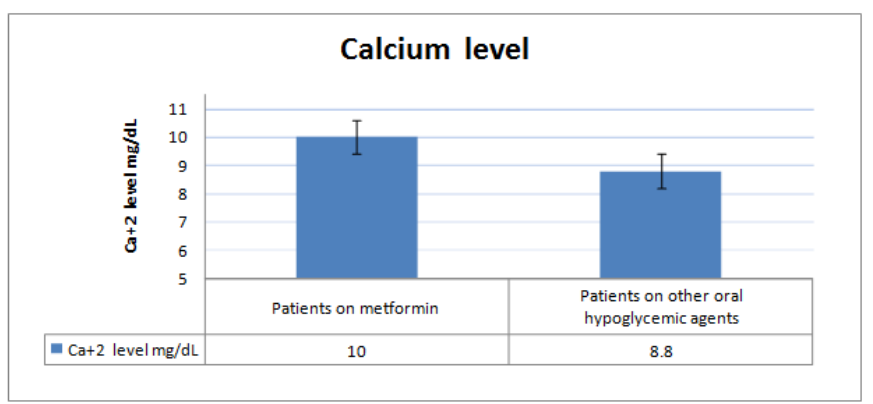

Figure 7. Potassium level in patients on metformin versus patients on other oral hypoglycemic agents.

The results revealed that $\mathrm{Hb} 1 \mathrm{Ac}$ for patients using metformin alone is significantly ( $\mathrm{P}$ value $<0.05$ ) higher than those using metformin combined with other OHAs (standard error $=0.041202$ and 0.006638 respectively) (Figure 8). 


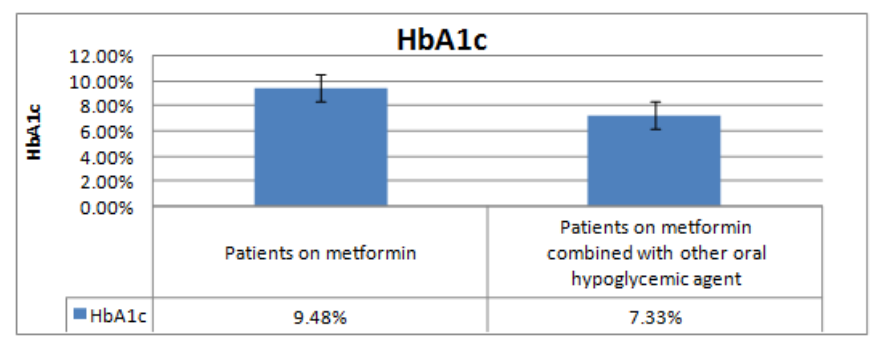

Figure 8. HbA1c levels in patients on metformin versus patients on metformin combined with other oral hypoglycemic agent.

\section{Discussion:}

In context of renal impairment and cautions, our survey result showed that neither the guidelines nor a lab test are consistently followed. Only $43 \%$ of physicians use the creatinine level, and only $57 \%$ of physicians performed the test every 3 months which is the typical time for follow up. i.e. roughly speaking only half of the physicians follow the guidelines. Our results are consistent with other studies in European countries which demonstrated that these guidelines are commonly disregarded (Holstein et al., 1999).

Lack of the proper test (GFR, creatinine clearance) in the public/ government hospital might be a crucial hinder to perform the right test. On the other hand, although metformin is the drug of choice in T2DM (Tahrani et al., 2007), according to our questionnaire only $84 \%$ of physicians prescribe this drug as first line of treatment and no contraindication had been identified.

Our study of sixty patients with T2DM was highly selective to decrease the confounder's effect. We compared metformin with other OHAs. In this case we have taken patient of 50 to 60 age having T2DM for 5 years treated with metformin only or with other OHAs, so that our study can be a "case- control study" for comparison of electrolyte levels.

A comparative study of metformin versus other hypoglycaemic agents illustrated that calcium is significantly elevated in metformin therapy compared to other OHAs. However, insignificant elevation of potassium and reduction of sodium values were recorded in patients taking metformin (Javaid et al., 2007). Another large study (>97000 patients) also reported high potassium and calcium in diabetic patients treated with metformin. In concession, this study was not a comparative one (EHealthMe, 2015). Nevertheless, our study was consistent with these studies. There was a significant increase of calcium level in patients using metformin alone compared to patients using other OHAs. The results also showed high potassium and low sodium levels in patients treated with metformin only compared with patients using other OHAs. However, both were still within the normal level and statistically insignificant. Metformin increases the excretion of $\mathrm{Na}+$ by enhancing its glomerular filtration rate (Dorella et al., 1996). Further studies needed to be done in concern to the effect of metformin on $\mathrm{Ca}+2$ and $\mathrm{K}+$ excretion.

Finally, $\mathrm{HbA} 1 \mathrm{c}$ was significantly low in patient having metformin combined with other OHAs compared with those having metformin only. Although none of them achieved the target level $(6.5 \%)$ but a significant difference between the means was cleared. Our results came in tandem with other results which support combination (Reasner et al., 2011) where metformin lower HbA1c more efficiently as combination than metformin therapy. However, combined oral hypoglycaemic agent do work better on $\mathrm{HbA1c}$ than monotherapy (Rockville, 2007)

\section{Conclusion and recommendations:}

1. National and local guidelines of metformin should be modified and restructured according to the clinical practice in relation to the mid-moderate kidney disease. A clear cut point level as red flag should be identified. Otherwise, guidelines will be overlooked and even disregarded in the clinical practice which current issue.

2. We need more randomised controlled clinical studies about electrolytes association with metformin for two folds. One to support the renal function relation or not without confounders or bias, and second to justify the significant difference between them.

3. HbA1c should be taken in consideration when treating T2DM with metformin as initial therapy, combination and or withdrawn from metformin, because secondary failure to achieve the target level HBA1c had been encountered. This was unfortunately overlooked at both guidelines and clinical practice and as an approached ladder to HbA1c target.

\section{References:}

ADMINISTRATION, U. F. A. D. 2014. Glucophage (metformin hydrochloride) [final printed labeling] [Online]. US: US Food and Drug 
Administration.

Available:

http://www.accessdata.fda.gov/drugsatfda_doc

s/nda/2000/20357S019_Glucophage_prntlbl.pdf

[Accessed 1st June 2015].

AMERICAN DIABETES, A. 2011. Diagnosis and classification of diabetes mellitus. Diabetes Care, 34, S62-S69.

BOWERS, L. D. \& WONG, E. T. 1980. Kinetic serum creatinine assays. II. A critical evaluation and review. Clin Chem, 26, 555-61.

CLINICAL, N. I. F. H. A. \& EXCELLENCE. 2015. The management of type 2 diabetes: 2010 NICE Guidelines [Internet]. [Online]. National Institute for Health and Clinical Excellence.Available: http://www.nice.org.uk/nicemedia/live/12165/4 4320/44320.pdf. [Accessed 1st July 2015 2015].

DORELLA, M., GIUSTO, M., DA TOS V., CAMPAGNOLO, M., PALATINI, P., ROSSI, G., CEOLOTTO, G., FELICE, M., SEMPLICINI, A. \& DEL PRATO, S. 1996. Improvement of insulin sensetivity by metformin treatment does not lower blood pressure of nonobese insulin-resistant hypertensive patients with normal glucose tolerance. $J$ Clin Endocranial Metab, 81(4): 1568-74.

EHEALTHME. Review: could metformin cause blood potassium increased (hyperkalemia)?

[Online].Available:

http://www.ehealthme.com/ds/metformin/bloo d+potassium+increased [Accessed 7/7/2015 2015].

EHEALTHME. 2015. Review: could metformin cause blood calcium increased? [Online]. Available:http://www.ehealthme.com/ds/metfo rmin/blood+calcium+increased [Accessed 7/7/2015 2015].

FAZELI FARSANI, S., VAN DER AA, M. P., VAN DER VORST, M. M., KNIBBE, C. A. \& DE BOER, A. 2013. Global trends in the incidence and prevalence of type 2 diabetes in children and adolescents: a systematic review and evaluation of methodological approaches. Diabetologia, 56, 1471-88.

FRID, A., STERNER, G. N., LÖNDAHL, M., WIKLANDER, C., CATO, A., VINGE, E. \& ANDERSSON, A. 2010. Novel assay of metformin levels in patients with type 2 diabetes and varying levels of renal function: Clinical recommendations. Diabetes Care, 33, 1291-1293.
GROUP, D. C. A. C. T. R. 1993. The effect of intensive treatment of diabetes on the development and progression of long-term complications in insulin-dependent diabetes mellitus. The diabetes control and complications trial research group. $\mathrm{N}$ Engl J Med, 329, 977-86.

GROUP, U. P. D. S. U. 1998a. Effect of intensive blood-glucose control with metformin on complications in overweight patients with type 2 diabetes (UKPDS 34). . Lancet, 352, 854-65.

GROUP, U. P. D. S. U. 1998b. Intensive blood-glucose control with sulphonylureas or insulin compared with conventional treatment and risk of complications in patients with type 2 diabetes (UKPDS 33). UK Prospective Diabetes Study (UKPDS) Group. Lancet, 352, 837-53.

HEMMINGSEN, B., CHRISTENSEN, L. L., WETTERSLEV, J., VAAG, A., GLUUD, C., LUND, S. S. \& ALMDAL, T. 2012. Comparison of metformin and insulin versus insulin alone for type 2 diabetes: systematic review of randomised clinical trials with meta-analyses and trial sequential analyses. Bmj, 344, e1771.

HOLSTEIN, A., NAHRWOLD, D., HINZE, S. \& EGBERTS, E. H. 1999. Contra-indications to metformin therapy are largely disregarded. Diabet Med, 16, 692-6.

INZUCCHI, S. E., LIPSKA, K. J., MAYO, H., BAILEY, C. J. \& MCGUIRE, D. K. 2014. Metformin in patients With type 2 diabetes and kidney disease: A Systematic Review. JAMA, 312, 2668-2675.

JANSSEN, J. W. \& HELBING, A. R. 1991. Arsenazo III: An improvement of the routine calcium determination in serum. Eur J Clin Chem Clin Biochem, 29, 197-201.

JAVAID, A., HASAN, R., ZAIB, A. \& MANSOOR, S. 2007. A comparative study of the effects of hypoglycemic agents on serum electrolytes in the diabetic patients. Pak J Pharm Sci, 20, 67-71.

KAHN, S. E., COOPER, M. E. \& DEL PRATO, S. 2014. Pathophysiology and treatment of type 2 diabetes: perspectives on the past, present, and future. Lancet, 383, 1068-83.

KDOQI. 2015. Clinical practice guidelines and clinical practice recommendations for diabetes and chronic kidney disease. [Online]. NKF KDOQI. Available:

http://www.kidney.org/professionals/KDOQI/gui deline_diabetes/guide2.htm

[Accessed 29/06/2015 2015]. 
MCMULlAN, A. D., BURNS, J. \& PATERSON, C. R. 1990. Venepuncture for calcium assays: should we still avoid the tourniquet? Postgrad Med J, 66, 547-8.

REASNER, C., OLANSKY, L., SECK, T. L., WILLIAMS-HERMAN, D. E., CHEN, M., TERRANELLA, L., JOHNSON-LEVONAS, A. O., KAUFMAN, K. D. \& GOLDSTEIN, B. J. 2011. The effect of initial therapy with the fixeddose combination of sitagliptin and metformin compared with metformin monotherapy in patients with type 2 diabetes mellitus. Diabetes Obes Metab, 13, 644-52.

RENA, G., PEARSON, E. R. \& SAKAMOTO, K. 2013. Molecular mechanism of action of metformin: old or new insights? Diabetologia, 56, 1898-906.

ROCKVILLE 2007. Comparing oral medications for adults with type 2 diabetes: Clinician's Guide.

Comparative effectiveness review summary guides for clinicians. 2007 ed. Eisenberg Center at Oregon Health \& Science University.

SAMBOL, N. C., CHIANG, J., LIN, E. T., GOODMAN, A. M., LIU, C. Y., BENET, L. Z. \& COGAN, M. G. 1995. Kidney function and age are both predictors of pharmacokinetics of metformin. J Clin Pharmacol, 35, 1094-102.

SOFRONESCU, A. G. 2013. CE-HPLC Testing of hemoglobin A1c for assessment of long term glycemic control in patients with diabetes mellitus. JSM Biochemistry \& Molecular Biology, 1.

TAHRANI, A. A., VARUGHESE, G. I., SCARPELLO, J. H. \& HANNA, F. W. F. 2007. Metformin, heart failure, and lactic acidosis: is metformin absolutely contraindicated? BMJ : British Medical Journal, 335, 508-512.

TALKE, H. \& SCHUBERT, G. E. 1965. [Enzymatic urea determination in the blood and serum in the warburg optical test]. Klin Wochenschr, 43, 1745.

TIETZ NW, P. E., SIGGAARD-ANDERSON O. 1994. Electrolytes. Tietz Textbook of Clinical Chemistry, Philadelphia, Saunders.

WALKER, B. R., COLLEDGE, N. R., RALSTON, S., PENMAN, I. D. \& ELSEVIER INC. 2014. Davidson's principles and practice of medicine. 22nd edition. Chuchill Livingstone Elsevier. 